\title{
VARIABILITY OF SEEDS OF THE INVASIVE SPECIES IMPATIENS GLANDULIFERA ROYLE (BALSAMINACEAE) AND THEIR MICROMORPHOLOGY
}

\author{
Irmina MaciejewsKa-RutKowska, BeAta Janczak \\ I. Maciejewska-Rutkowska, B. Janczak, Department of Forest Botany, Poznań University of Life Sciences, \\ Wojska Polskiego 71 D, 60-625 Poznań, Poland, e-mail: irminamr@up.poznan.pl, beatajanczak@caldesia.pl
}

(Received: October 10, 2016. Accepted: November 28, 2016)

\begin{abstract}
The aim of the work was to estimate the range of morphological variability of seeds of the Himalayan balsam (Impatiens glandulifera), from different sites within Poland. It was also verified whether there was a correlation between morphological variability of seeds and type of vegetation from which they originated. Additionally, the seed coat ultrastructure of this species was studied. Biometrical analysis showed remarkable variability of seed morphology. A significant relationship between seed size and type of vegetation was also revealed. However, there was no clear relationship between seed mass and type of vegetation. Based on the structure and ornamentation of epidermal cells, the rugosely ruminate seed coat type was proposed.
\end{abstract}

KEY WORDS: Impatiens glandulifera, seeds, morphology, variability

\section{INTRODUCTION}

Impatiens L. (Balsaminaceae) is estimated to contain over 1000 species, mainly distributed in the tropical and subtropical mountain regions of the Old World. In contrast, only a few species of the genus are represented in the temperate regions in northern Asia, Europe and North America (Song et al. 2003, JANSSENS et al. 2006). Impatiens noli-tangere L. is the only balsam species native to Europe. Additionally, five others have been naturalised here (I. balsamina L., I. balfourii Hook. f., I. glandulifera Royle and I. parviflora D.C., all from Asia, and I. capensis Meerb. from North America; Moore 2010).

Impatiens glandulifera is an annual plant native to the western Himalaya mountains, from Kashmir to Garhwal regions, but since about 150 years ago it has become one of the most widespread invasive species in Europe (Kollmann \& Bañuelos 2004). Especially, the predominance of I. glandulifera along riverbanks has been observed and it is considered to be a significant conservation problem in riparian sites (HejDA \& PyšeK 2006, Hulme \& Bremner 2006). It is also included in the group of the top 20 invasive alien plants in Poland, found throughout the country, but with more frequent sites in the south (TOKARSKA-GuZIK 2005).
The seeds of Impatiens originate from anatropous ovules, with unitegmic, bitegmic or intermediate integuments according to the species (MCABEE et al. 2005). They are small- to medium-sized, non-endospermic and exalbuminous, with straight embryo. The seed coat is formed by the expanded chalaza, since the testa, mesophyll and tegmen are unspecialised and crushed to various degrees (HEGI 1924, CORNER 1976).

The seed micromorphology in the genus has been recognised by many researchers for at least 170 species, mainly originating from south and south-western Asia (Lu \& Chen 1991, Song et al. 2005, UtAmI \& Shimizu 2005, Song 2006, Wei et al. 2007, Abid et al. 2011). All those studies underlined the taxonomic significance of the seed coat morphology. ABID et al. (2011) considered the seed characters to be significant enough to correlate the delimitation of the genus Impatiens both at species and infra-species level. However, according to Utami \& SHimizu (2005) as well as Song (2006), seed morphology alone did not provide universally applicable key characters for species identification. Lu \& CHEN (1991) proved the evolution of seed coat of Impatiens species to have a close correlation with that of the flower and pollen morphology. In turn, SoNG et al. (2005) studied seed 
micromorphology to provide evidence for tracing taxonomic and phylogenetic relationships within the Impatiens genus.

The seeds of I. glandulifera have been the subject of some investigations on their embryo mass and size, on biology and mechanics of dispersion and biology of germination (e.g. Mumford 1990, Willis \& Hulme 2004, Chapman \& Gray 2012). Though the seeds of I. glandulifera were taken into consideration by UTAMI \& Shimizu (2005) in their work on the seed micromorphology of Asiatic Impatiens species, the authors did not comment on or illustrate the results of their observations in respect to this taxon at all. The seed morphology of I. glandulifera was also given attention by ABID et al. (2011) in their study on Pakistan Impatiens species, but without a comprehensive survey.

The main aim of our work was to estimate the range of morphological variability of seeds of $I$. glandulifera. We also wanted to prove whether there was a correlation between morphological variability of seeds and type of vegetation from which they originated. Additionally, we studied the ultrastructural traits of seeds of I. glandulifera.

\section{MATERIALS AND METHODS}

Eight seed samples of I. glandulifera were taken from the field (Table 1). Plant material was gathered from the sites with the species populations with at least 50 individuals in the optimal condition, with a height of about $150-200 \mathrm{~cm}$, intimately branched. At the same the most common plant communities in Poland with the observed taxon were taken into account (MATUSZKIEWICZ 2001, TOKARSKA-GUZIK 2005). All examinations were carried out on fully developed seeds. Studied plant material was not specially prepared, but only dried and cleaned. For each population 50 seeds were weighed on the analytical balance (OHAUS, Analytical Plus Model AP 250 DE).
The vegetation terminology was applied by MATUSZKIEWICZ (2001).

The SEM observations were analysed according to Barthlott's method $(1981,1984)$. The seeds were mounted on stubs and coated with gold in a sputter coater and examined with a Hitachi S3000N field emission scanning electron microscope at $5 \mathrm{kV}$ in the Research Centre of Quarantine, Invasive and Genetically Modified Organisms in Poznan (Poland). The descriptions of seed morphology were based on the terminology presented by STERN (2004) and BOJŇANSKÝ \& FARGAŠOVÁ (2007).

Biometry was done using the DigiShape 1.9.220 computer program (Cortex Nova 2005, Poland). For each sample 150 seeds were analysed. The following seed traits were measured: length $(\mathrm{mm})$, width $(\mathrm{mm})$, elongation (= length/width), perimeter $(\mathrm{mm})$, area $\left(\mathrm{mm}^{2}\right)$ and circularity $\left[=\right.$ perimeter $^{2} /$ $(\pi \times$ area $)]$. The analysis of the obtained data was performed with the computer program Statistica 6 . The descriptive statistics - arithmetic mean, minimum value, maximum value, standard deviation (SD) and coefficient of variation (CV) - were calculated for each of the above-mentioned traits. One factor analysis of variance (ANOVA) at the significant level $\alpha=$ 0.05 was carried out. Significant differences between the means were determined by Tukey's HSD test. Jentys-Szaferowa's method (1959) based on the ratio of the trait values of each population to the general mean was used to characterise the morphological variation of seeds.

\section{RESULTS}

\section{MORPHOLOGICAL VARIABILITY OF SEEDS}

The most frequent seeds were globose, subglobose, obovoid, broadly elliptic or elliptic and only occasionally lanceolate. The apex was obtuse, the base

Table 1. The origin, participation in vegetation and weight of 50 seeds (g) of investigated populations of Impatiens glandulifera

\begin{tabular}{|c|c|c|c|c|c|}
\hline $\begin{array}{l}\text { No. of } \\
\text { popu- } \\
\text { lation }\end{array}$ & $\begin{array}{l}\text { Site name } \\
\text { Province }\end{array}$ & $\begin{array}{l}\text { Geographical } \\
\text { coordinates }\end{array}$ & Participation in vegetation & $\begin{array}{l}\text { Date of seed } \\
\text { collection }\end{array}$ & $\begin{array}{l}\text { Weight of } \\
50 \text { seeds }(\mathrm{g})\end{array}$ \\
\hline 1. & $\begin{array}{l}\text { Police } \\
\text { West Pomerania }\end{array}$ & 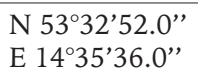 & rush with reeds (Phragmitetum australis) & 21.09 .2005 & 1.138 \\
\hline 2. & $\begin{array}{l}\text { Szamotuły } \\
\text { Wielkopolska }\end{array}$ & $\begin{array}{l}\text { N 52 } 36^{\prime} 53.0^{\prime \prime} \\
\text { E } 16^{\circ} 34^{\prime} 27.0^{\prime \prime}\end{array}$ & rush with reeds (Phragmitetum australis) & 07.10 .2005 & 1.352 \\
\hline 3. & $\begin{array}{l}\text { Kopanina } \\
\text { Wielkopolska }\end{array}$ & $\begin{array}{l}\text { N } 52^{\circ} 22^{\prime} 36.5^{\prime \prime} \\
\text { E } 16^{\circ} 51^{\prime} 35.3^{\prime \prime}\end{array}$ & rush with reeds (Phragmitetum australis) & 13.09 .2007 & 1.383 \\
\hline 4. & $\begin{array}{l}\text { Dziwnów } \\
\text { West Pomerania }\end{array}$ & $\begin{array}{l}\text { N } 54^{\circ} 01^{\prime} 36.0^{\prime \prime}, \\
\text { E } 14^{\circ} 46^{\prime} 04.0^{\prime \prime}\end{array}$ & herbaceous plants (Artemisietea vulgaris class) & 04.09 .2012 & 1.422 \\
\hline 5. & $\begin{array}{l}\text { Rudnik } \\
\text { Lublin }\end{array}$ & $\begin{array}{l}\text { N } 50^{\circ} 52^{\prime} 50.0^{\prime \prime} \\
\text { E } 22^{\circ} 58^{\prime} 18.0^{\prime \prime}\end{array}$ & herbaceous plants (Artemisietea vulgaris class) & 12.09 .2012 & 1.525 \\
\hline 6. & $\begin{array}{l}\text { Raduszyn } \\
\text { Wielkopolska }\end{array}$ & $\begin{array}{l}\text { N 52॰34'25.0”' } \\
\text { E 1659'32.0”' }\end{array}$ & herbaceous plants (Artemisietea vulgaris class) & 16.09 .2012 & 1.344 \\
\hline 7. & $\begin{array}{l}\text { Wierzbica } \\
\text { Lublin }\end{array}$ & $\begin{array}{l}\text { N 50॰52'31.0”, } \\
\text { E 2255'31.0”' }\end{array}$ & riparian forest (Fraxino-Alnetum) & 13.09 .2012 & 1.357 \\
\hline 8. & $\begin{array}{l}\text { Naramowice } \\
\text { Wielkopolska }\end{array}$ & $\begin{array}{l}\text { N } 52^{\circ} 27^{\prime} 40.5^{\prime \prime} \\
\text { E } 16^{\circ} 57^{\prime} 47.3^{\prime \prime}\end{array}$ & herbaceous plants (Artemisietea vulgaris class) & 16.09 .2012 & 1.434 \\
\hline
\end{tabular}


Fig. 1. Comparison of the lines of size and shape of the investigated samples of seeds of Impatiens glandulifera (broken lines) to the total sample (straight line)

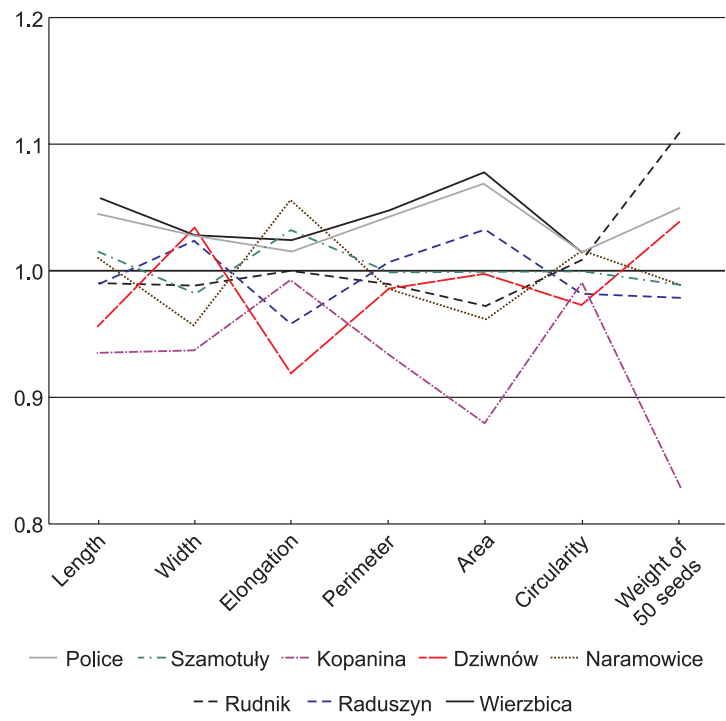

Table 2. Descriptive statistics of the quantitative data of the populations of Impatiens glandulifera

\begin{tabular}{|c|c|c|c|c|c|c|c|c|c|}
\hline Population & 1. Police & $\begin{array}{l}\text { 2. Szamo- } \\
\text { tuły }\end{array}$ & $\begin{array}{l}\text { 3. Kopani- } \\
\text { na }\end{array}$ & $\begin{array}{l}\text { 4. Dziw- } \\
\text { nów }\end{array}$ & 5. Rudnik & $\begin{array}{l}\text { 6. Ra- } \\
\text { duszyn }\end{array}$ & $\begin{array}{l}\text { 7. Wierz- } \\
\text { bica }\end{array}$ & $\begin{array}{l}\text { 8. Nara- } \\
\text { mowice }\end{array}$ & Totally \\
\hline \multicolumn{10}{|c|}{ Length (mm) } \\
\hline Mean & 3.26 & 3.53 & 3.52 & 3.32 & 3.45 & 3.45 & 3.68 & 3.64 & 3.48 \\
\hline Min. & 2.30 & 2.74 & 2.62 & 2.81 & 2.46 & 2.81 & 2.81 & 2.69 & 2.30 \\
\hline Max. & 4.20 & 4.31 & 4.31 & 3.95 & 4.65 & 4.25 & 4.57 & 4.39 & 4.65 \\
\hline SD & 0.37 & 0.34 & 0.33 & 0.34 & 0.23 & 0.40 & 0.29 & 0.39 & 0.37 \\
\hline $\mathrm{CV} \%$ & 10.43 & 9.35 & 9.66 & 6.93 & 11.59 & 8.41 & 10.60 & 10.16 & 10.63 \\
\hline \multicolumn{10}{|c|}{ Width (mm) } \\
\hline Mean & 2.66 & 2.78 & 2.71 & 2.93 & 2.80 & 2.90 & 2.91 & 2.91 & 2.83 \\
\hline Min. & 1.78 & 2.15 & 1.85 & 2.21 & 2.02 & 2.37 & 2.29 & 2.17 & 1.78 \\
\hline Max. & 3.48 & 3.51 & 3.47 & 3.58 & 3.67 & 3.49 & 3.76 & 3.66 & 3.76 \\
\hline $\mathrm{SD}$ & 0.29 & 0.31 & 0.32 & 0.24 & 0.34 & 0.24 & 0.30 & 0.31 & 0.31 \\
\hline $\mathrm{CV} \%$ & 10.90 & 11.15 & 11.81 & 8.19 & 12.14 & 8.28 & 10.31 & 10.65 & 10.95 \\
\hline \multicolumn{10}{|c|}{ Elongation } \\
\hline Mean & 1.24 & 1.28 & 1.31 & 1.14 & 1.24 & 1.19 & 1.27 & 1.26 & 1.24 \\
\hline Min. & 1.00 & 1.00 & 1.00 & 1.00 & 1.00 & 1.00 & 1.00 & 1.00 & 1.00 \\
\hline Max. & 2.05 & 1.67 & 2.08 & 1.59 & 1.88 & 1.51 & 1.60 & 1.60 & 2.08 \\
\hline $\mathrm{SD}$ & 0.14 & 0.16 & 0.20 & 0.10 & 0.18 & 0.12 & 0.14 & 0.14 & 0.16 \\
\hline $\mathrm{CV} \%$ & 11.29 & 12.50 & 15.27 & 8.77 & 14.52 & 10.08 & 11.02 & 11.11 & 12.90 \\
\hline \multicolumn{10}{|c|}{ Perimeter (mm) } \\
\hline Mean & 9.49 & 10.16 & 10.01 & 10.02 & 10.06 & 10.22 & 10.64 & 10.58 & 10.15 \\
\hline Min. & 7.19 & 8.36 & 8.06 & 8.56 & 8.04 & 8.74 & 8.32 & 8.17 & 7.19 \\
\hline Max. & 11.97 & 12.09 & 12.30 & 12.08 & 13.12 & 11.98 & 12.82 & 12.58 & 13.12 \\
\hline SD & 0.89 & 0.89 & 0.87 & 0.67 & 1.08 & 0.76 & 1.06 & 1.06 & 0.98 \\
\hline $\mathrm{CV} \%$ & 9.38 & 8.76 & 8.69 & 6.69 & 10.74 & 7.44 & 9.96 & 10.02 & 9.66 \\
\hline \multicolumn{10}{|c|}{ Area $\left(\mathrm{mm}^{2}\right)$} \\
\hline Mean & 6.17 & 6.98 & 6.74 & 6.99 & 6.81 & 7.23 & 7.55 & 7.49 & 6.70 \\
\hline Min. & 3.40 & 4.61 & 4.42 & 4.98 & 4.44 & 5.02 & 4.68 & 4.68 & 3.40 \\
\hline Max. & 9.37 & 9.78 & 10.15 & 9.50 & 10.70 & 9.49 & 11.17 & 9.92 & 11.17 \\
\hline SD & 1.12 & 1.17 & 1.21 & 0.91 & 1.30 & 0.99 & 1.36 & 1.33 & 1.25 \\
\hline $\mathrm{CV} \%$ & 18.15 & 16.76 & 17.95 & 13.02 & 19.09 & 13.69 & 18.01 & 17.76 & 18.66 \\
\hline \multicolumn{10}{|c|}{ Circularity } \\
\hline Mean & 1.17 & 1.18 & 1.20 & 1.15 & 1.19 & 1.16 & 1.20 & 1.20 & 1.18 \\
\hline Min. & 1.07 & 1.09 & 1.09 & 1.06 & 1.06 & 1.07 & 1.10 & 1.09 & 1.06 \\
\hline Max. & 1.44 & 1.40 & 1.36 & 1.25 & 1.47 & 1.36 & 1.34 & 1.37 & 1.47 \\
\hline SD & 0.06 & 0.05 & 0.06 & 0.04 & 0.07 & 0.04 & 0.05 & 0.05 & 0.06 \\
\hline CV\% & 5.13 & 4.24 & 5.00 & 3.48 & 5.88 & 3.45 & 4.17 & 4.17 & 5.08 \\
\hline
\end{tabular}



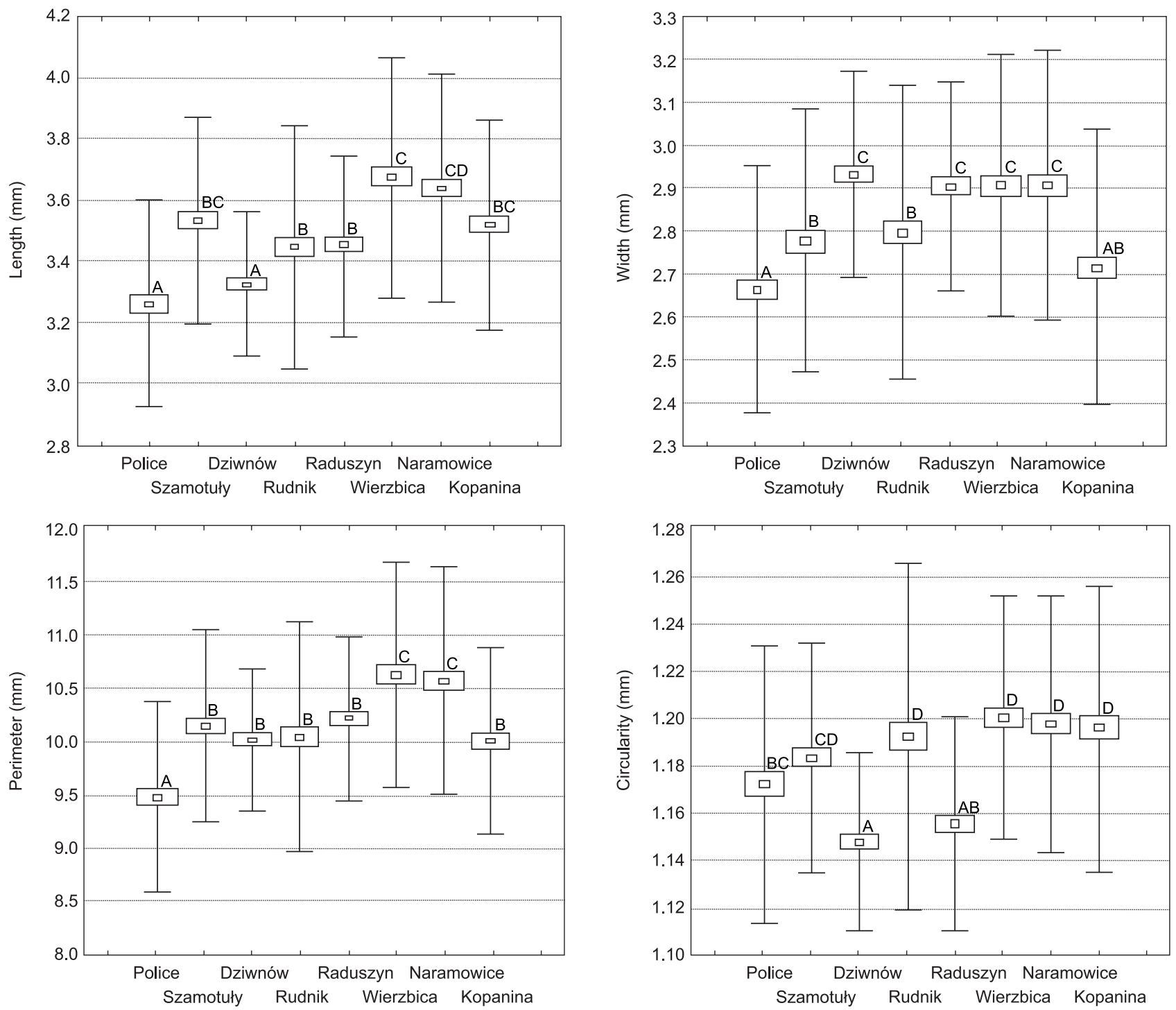

Fig. 2. Diagrams show the range of variation of six traits of Impatiens glandulifera seed samples (length, width, elongation, perimeter, area, circularity) according to their origin (Police, Szamotuły, Dziwnów, Rudnik, Raduszyn, Wierzbica, Naramowice, Kopanina). The same capital letters mean the values do not differ significantly $(\alpha=0.05)$

Signs: $\square$ - the arithmetic mean, AA - standard deviation, $\perp_{\top}-$ standard error.

tapered into a short beak. The hilum was basal. The seeds were on average (2.30-) $3.48(-4.65) \mathrm{mm}$ long and (1.78-) $2.83(-3.76) \mathrm{mm}$ wide, with the mean elongation $1.24 \mathrm{~mm}$, mean perimeter $10.15 \mathrm{~mm}$, mean area $6.70 \mathrm{~mm}^{2}$ and circularity 1.18 (Fig. 1, Table 2).

A significant influence of population origin on the values of all analysed traits was found (for each trait $p<0.01)$. On average, the smallest seeds were noted in the Police population and the largest in Wierzbi$\mathrm{ca}$ and Naramowice populations. At the same time, the first-mentioned population had the lightest seeds and the latter the heaviest, while the seed mass of the Wierzbica population did not visibly differ from the average value calculated for all populations (Figs $1-2$, Table 1).

The widest seeds were observed in the Dziwnów population and at the same time these ones had the lowest values of elongation and circularity. The most elongated seeds were observed in Kopanina, Wierzbica and Naramowice populations (Figs 1-2, Table 2).

In general, the most variable trait was area, with an average CV of $18.66 \%$ and the least variable was circularity, with an average CV $5.08 \%$. The lowest values of $\mathrm{CV}$ for all studied traits were found in the Dziwnów population and the highest, always above the total average CV (calculated for all seeds together), in the Rudnik population (Table 2).

A significant influence of vegetation type on the values of all traits of investigated seeds was also found (length $-\mathrm{p}<0.000001$, width $-\mathrm{p}<0.01$, elongation $-\mathrm{p}<0.000001$, perimeter $-\mathrm{p}<0.01$, area $-p<0.01$, circularity $-p<0.00001)$. The highest values of all analysed traits were observed for seeds collected from riparian forest, but it must be noted that there was only one such population (Wierzbica). Then, the smallest seeds were found in the populations growing in the rushes (Fig. 3). 


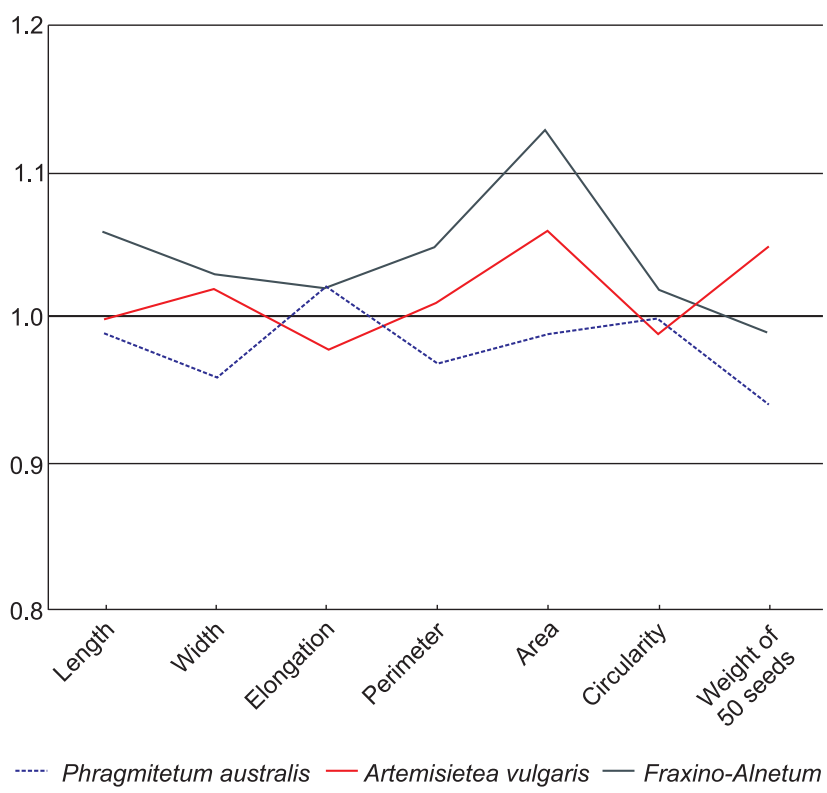

Fig. 3. Comparison of lines of size and shape of the investigated samples of seeds of Impatiens glandulifera, grouped in accordance to the type of vegetation (broken lines) to the total sample (straight line)

\section{MICROMORPHOLOGY OF SEED COAT}

The seed coat has an irregular, scabrous surface, rugosely ruminate in lower magnification, with irregular channels among the bulgy patches (Fig. 4a-b). The outer epidermal cells of seed coat are isodiametric or slightly elongated, amoeboid or rounded (Fig. 4c). Their periclinal walls are evenly, but slightly convex, of reticulate-foveate ornamentation. Additionally, there are some porous interspaces, scattered over the entire surface of the seed coat (Fig. 4d). The anticlinal walls are curved or visibly undulate. The glands originating from the central part of a single epidermal cell are sparse, mainly in the zone of the seed base. They are blunt, about $5 \mu \mathrm{m}$ long. Fine, scarce cuticle dusts can be seen under high magnification (Fig. 4e-f).

\section{DISCUSSION}

Values of coefficient of variation over $5 \%$ are often considered as 'large' in biological systems (Michaels et al. 1988). According to this criterion, we observed remarkable variability in quantitative seed traits in all analysed populations of I. glandulifera, with the exception of circularity, which proved to be relatively constant (CVs fluctuated about 5\%).

According to BeErling \& Perrins (1993) seeds of I. glandulifera are among the largest for annual plants in the British flora and they are 4-7 $\mathrm{mm}$ long and 2-4 mm wide. In our study, the seeds of this species collected within the area of Poland are smaller. The difference is especially distinct in relation to seed length, which is $2-3 \mathrm{~mm}$ shorter than the length cited above. In turn, with regard to the seed size the
Polish populations of this species are similar to the populations from the Czech Republic (length 3.97 $\mathrm{mm} \pm 0.47$, width $2.82 \mathrm{~mm} \pm 0.38$; Moravcová et al. 2010). However, the seeds within the area of Bohemia are on average more elongated (length/width ratio $1.42 \pm 0.19$ ).

BeERLING \& PerRins (1993) reported air-dried seed mass of $I$. glandulifera in the range of $2-35 \mathrm{mg}$. An even greater range of fresh mass of single seed (33$478 \mathrm{mg}$ ), with the mean population CV in seed mass nearly $40 \%$, was noted by WiLlis \& Hulme (2004). In this experiment seed mass variation was the greatest among individual plants and was the lowest among populations. In the current study we did not observe such significant differences in seed mass populations. We estimated the mean mass of single dried seed of $27 \mathrm{mg}$, with the range $23-31 \mathrm{mg}$. At the same time, the seeds of the smallest mass were of the smallest sizes, but more surprisingly, the seeds with the greatest mass were not found to be the largest ones.

Impatiens glandulifera occurs in many different sites, but it prefers moist and nutrient rich ones, especially on lake- and seashores and along rivers and streams. In Central Europe this species is attributed to riparian alien species, but the biotopes that are most suitable for it are those that have been affected by human activities (HelmisaAri 2010). We did not observe a clear relationship between seed mass and type of vegetation, although on average seed mass from herbaceous plant communities was somewhat greater $( \pm 2 \mathrm{mg})$ than from riparian forest and rushes. On the other hand, we revealed a significant relationship between seed size and type of vegetation, finding the largest seeds in the population from riparian forest. There were also differences in seed size between the populations from rushes and herbaceous plants, with the predominance of the latter. An influence of site conditions on seed size is not unequivocal. For instance, LeISHMAN et al. (1995) comparing five temperate floras, stated that seed size was more strongly associated with other plant attributes, such as growth form or dispersal mode, than with the environmental conditions. In turn, no consistent ecological (dispersal mode and growth form) correlates of variance of seed mass were evident in the study by Michaels et al. (1988) on the seeds of 39 American species. TANNER (2011) found that I. glandulifera produced heavier seeds in the native range compared to the introduced range. The author thought that in the Himalayas, the severity of the winter induced a smaller number of seeds per plant but with a higher biomass. Outside its native range a higher number of seeds with lower biomass might be an adaptation of the population to a more tolerable climate. WiLLIS \& Hulme (2004) noted a significant trend of seed mass increasing in I. glandulifera populations within the United Kingdom with higher elevation of the site. 


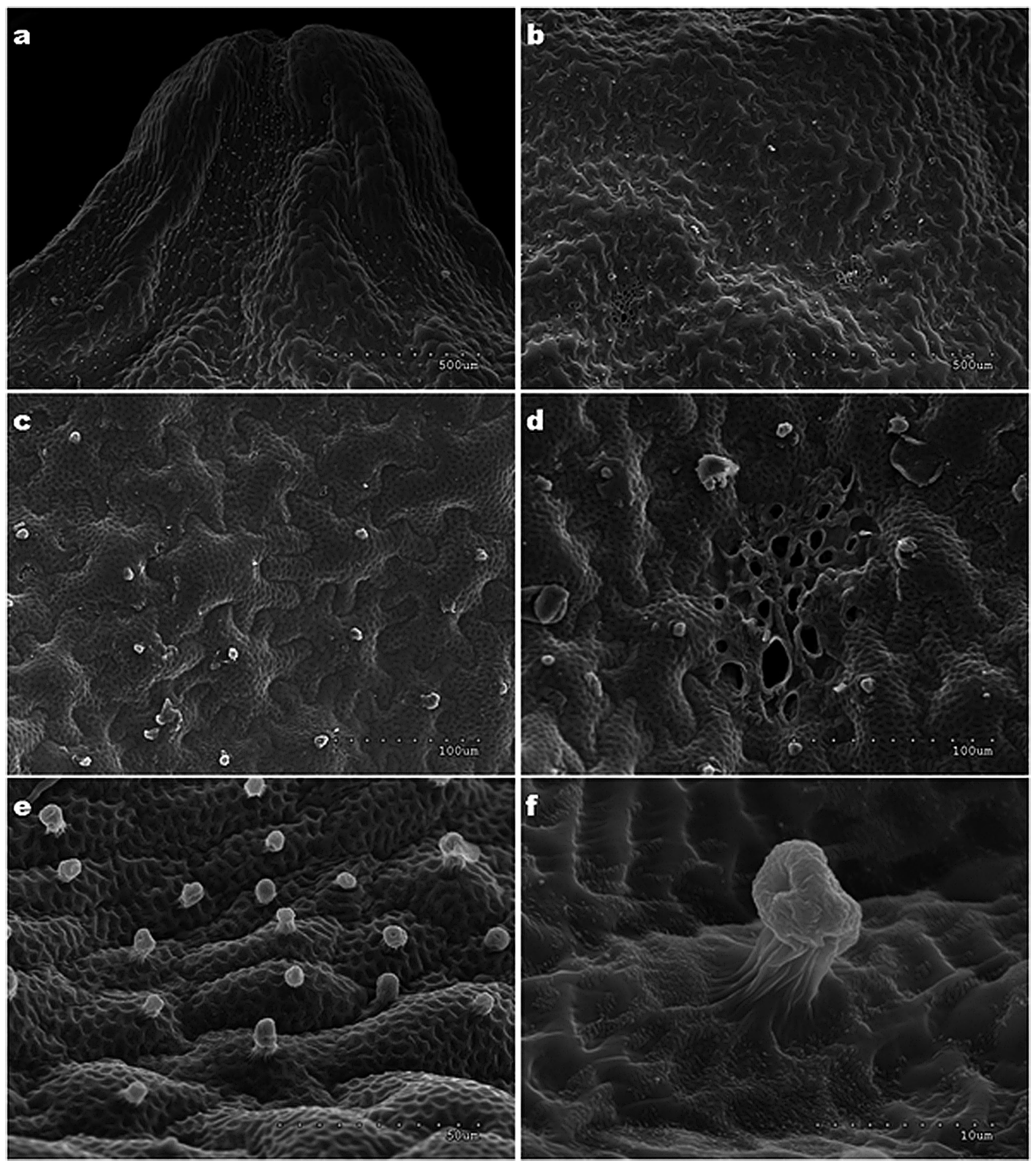

Fig. 4. Details of seed surface of Impatiens glandulifera: a) general view at the basal zone, b) general view at the central part of the dorsal side, c) focus on ameboid outline of cells, d) focus on porous interspaces, e) reticulate-foveate ornamentation of periclinal walls with centrally placed glands, f) focus on gland structure, delicate cuticle dust visible

Particular species of Impatiens have an unusually diverse and elaborately sculptured seed coat; hence many different types of seed sculpture have been distinguished within this genus so far. Laevigate, granulate, reticulate and protrusive types of surface patterns of the Impatiens species are most commonly described (Lu \& CHEN 1991, Song et al. 2005, UTAMI \& Shimizu 2005, Wei et al. 2007, ABID et al. 2011). In our opinion, the seed surface of I. glandulifera, previ- ously determined as rugosely areolate, and egranulate (ABID et al. 1.c.), represents the rugosely ruminate seed coat type defined in this study. At the same time, we observed an amoeboid outline of the periclinal walls, which had not been described previously in the seeds of this genus (basing on literature data cited above at most curved walls were observed). We also noted the delicate glands in the central part of the cells of seed-coat of I. glandulifera. According to 
the literature (cited above) the presence of glandular structures was often observed in others seeds in Impatiens subgenus. However, all those properties: reticulate-foveate ornamentation of seed coat cells, undulate arrangement of cell walls and presence of glands constitute a unique combination of traits, purely characteristic for the investigated species. Additionally, we noted some sieve-like interspaces, so far described only in seeds of $I$. conchibracteata (Lu \& CHen 1991).

\section{ACKNOWLEDGMENTS}

This study was supported by the statutory activity of Department of Forest Botany of Poznań University of Life Sciences. We thank Magdalena Gawlak (the Institute of Plant Protection in Poznań) for the SEM photographs.

\section{REFERENCES}

Abid R., Ather A., Qaiser M. (2011): The seed atlas of Pakistan-V. Balsaminaceae. Pakistan Journal of Botany 43(5): 2451-2456.

BARTHLOtT W. (1981): Epidermal and seed surface characters of plants: systematic applicability and some evolutionary aspects. Nordic Journal of Botany $1(3)$ : $345-355$.

BarthlotT W. (1984): Microstructural features of seed surfaces. In: V.H. Heywood, D.A. Moore (eds). Current concepts in plant taxonomy. Academic Press, London: 95-105.

BeErling D.J., Perrins J.M. (1993): Biological flora of the British isles. Impatiens glandulifera Royle (Impatiens roylei Walp.). Journal of Ecology 81(2): 367-382.

BojŇAnsKÝ V., FARGašová A. (2007): Atlas of seeds and fruits of Central and East-European flora. The Carpathian mountains region. Springer, Dordrecht.

Chapman D.S., Gray A. (2012): Complex interactions between the wind and ballistic seed dispersal in Impatiens glandulifera (Royle). Journal of Ecology 100(4): 874-883.

Corner E.J.H. (1976): Seeds of dicotyledons. Cambridge University Press, Cambridge.

Hegi G. (1924): Illustrierte Flora von Mittel-Europa. Mit besonderer Berücksichtigung von Deutschland, Österreich und der Schweiz. Band 5, Teil 1. Carl Hanser Verlag, München.

Hejda M., PYšEK P. (2006): What is the impact of Impatiens glandulifera on species diversity of invaded riparian vegetation? Biological Conservation 132: 143-152.

HelmisaAri H. (2010): NOBANIS - Invasive Alien Species Fact Sheet - Impatiens glandulifera. Online Database of the North European and Baltic Net- work on Invasive Alien Species. Available from: http://www.nobanis.org. (access: 15.09.2016).

Hulme P.E., Bremner E.T. (2006): Assessing the impact of Impatiens glandulifera on riparian habitats: partitioning diversity components following species removal. Journal of Applied Ecology 43: 3-50.

Janssens S.B., Geuten K., Yuan Y.-M., Song Y., Küpfer Ph., SMets E. (2006): Phylogenetics of Impatiens and Hydrocera (Balsaminaceae) using chloroplast atpB-rbcL spacer sequences. Systematic Botany 31(1): 171-180.

Jentys-SzAFEROWA J. (1959): A graphical method of comparing the shapes of plants. Review of the Polish Academy of Sciences 4(1): 9-38.

Kollmann J., Bañuelos M.J. (2004): Latitudinal trends in growth and phenology of the invasive alien plant Impatiens glandulifera (Balsaminaceae). Diversity and Distributions 10(5-6): 377-385.

Leishman M.R., Westoby M., Jurado E. (1995): Correlates of seed size variation among five temperate floras. Journal of Ecology 83(3): 517-530.

Lu Y.-Q., Chen Y.-L. (1991): Seed morphology of Impatiens L. (Balsaminaceae) and its taxonomic significance. Acta Phytotaxonomica Sinica 29: 252-257.

Matuszkiewicz W. (2001): Przewodnik do oznaczania zbiorowisk roślinnych w Polsce. Wyd. Nauk. PWN, Warszawa.

McAbee J.M., Kuzoff R.K., Gasser Ch.S. (2005): Mechanisms of derived unitegmy among Impatiens species. The Plant Cell 17(6): 1674-1684.

Michaels H.J., Benner B., Hartgerink A.P., Lee T.D., Rice S., Willson M.F., Bertin R.I. (1988): Seed size variation: magnitude, distribution, ecological correlates and ecological correlates. Evolutionary Ecology 2: 157-166.

Moore D.M. (2010): Impatiens L. In: T.G. Tutin, V.H. Heywood, N.A. Burges, D.M. Moore, D.H. Valentine, S.M. Walters, D.A. Webb (eds). Flora Europaea 2. Rosaceae to Umbeliferae. Cambridge University Press, Cambridge: 240-241.

Moravcová L., PYšEK P., JarošíK V., HavlíčKová V., ZÁKRAVSKÝ P. (2010): Reproductive characteristics of neophytes in the Czech Republic: traits of invasive and non-invasive species. Preslia 82(4): 365-390.

MumFord P.M. (1990): Dormancy break in seeds of Impatiens glandulifera Royle. New Phytologist 115(1): 171-175.

Song Y. (2006): Evolution and biogeography of Balsaminaceae: insights from molecular phylogeny. $\mathrm{PhD}$ thesis. University of Neuchâtel-Faculty of Science-Evolutionary Botany Laboratory, Neuchâtel-Switzerland. Available from: http://doc.rero. ch/record/6210/files/these_SongY.pdf (access: 10.09.2016).

Song Y., Yuan Y.-M., KüPfer P. (2003): Chromosomal evolution in Balsaminaceae, with cytological 
observations on 45 species from Southeast Asia. Caryologia 56(4): 463-481.

Song Y., Yuan Y.-M., KüPfer P. (2005): Seedcoat micromorphology of Impatiens (Balsaminaceae) from China. Botanical Journal of the Linnean Society 149: 195-208.

STERN W.T. (2004): Botanical latin. David \& Charles, Timber Press, Singapore.

TANNER R.A. (2011): An ecological assessment of Impatiens glandulifera in its introduced and native range and the potential for its classical biological control. PhD thesis, Royal Holloway, University of London. Available from: http://www.pure.rhul. ac.uk/portal/files/4459536/2012Tannerraphd. pdf (access: 15.09.2016).

TOKARsKa-GuzIK B. (2005): The establishment and spread of alien plant species (kenophytes) in the flora of Poland. Wyd. Uniwersytetu Śląskiego, Katowice.
Utami N., Shimizu T. (2005): Seed morphology and classification of Impatiens (Balsaminaceae). Blumea 50(3): 447-456.

Wei Ch., Ke-Ming L., Xiu-Zhen C., Yi-Yan C. (2007): Micromorphological features of fourteen species in Impatiens (Balsaminaceae) in relation to their taxonomic significance. Acta Botanica Yunnanica 29(6): 625-631.

Willis S.G., Hulme P.E. (2004): Environmental severity and variation in the reproductive traits of Impatiens glandulifera. Functional Ecology 18(6): 887-898.

For citation: MACIEjeWSKA-RUTKOWSKA I., JANCZAK B. (2016): Variability of seeds of the invasive species Impatiens glandulifera Royle (Balsaminaceae) and their micromorphology. Steciana 20(4): 183-190. doi: 10.12657/steciana.020.019 